JMKSP (Jurnal Manajemen, Kepemimpinan, dan Supervisi Pendidikan)

Volume 7 Issue 1 (2022) Page 1-18

ISSN 2614-8021 (Online) 2548-7094 (Print)

\title{
E-Module as Conflict Resolution: The Application of Pancasila Values in Analyzing Cases of Violation and Denial of Citizen Rights and Obligations
}

\author{
Nosy Mutia Angraini ${ }^{1}$, Susi Fitria Dewi ${ }^{1}$ Fatmariza $^{1}$, Suhono $^{2}$, Yayuk \\ Hidayah $^{3}$ \\ ${ }^{1}$ Universitas Negeri Padang \\ ${ }^{2}$ Institut Agama Islam Ma'arif NU (IAIMNU) Metro Lampung \\ ${ }^{3}$ Universitas Ahmad Dahlan Yogyakarta \\ Corresponding Author E-mail: nosy.angraini@gmail.com
}

Received 20 July 2021; Revised 21 August 2021; Accepted 2 January 2022

\begin{abstract}
The conflict resolution e-module for $\mathrm{KD}$ is the relevance of applying the values of Pancasila in analyzing cases of violations and denial of the rights and obligations of citizens, in the subject of PPKn SMA class XII semester 1, serves as a practical learning medium for high school students to be able to understand and resolve conflicts. This study aims to assist students in recognizing various cases of violations and denial of the rights and obligations of citizens so that awareness of their rights and obligations as citizens can grow, with the hope of becoming good citizens who can avoid or manage conflicts well. This research is deliberately and systematically aimed or directed to be able to find or formulate products, models, media, methods, and certain strategies that are more effective, efficient and innovative. The research model used in This study is a Plomp research model which is an adaptation of the model developed by Tjeerd Plomyang. This model was chosen because it is more systematic, directed, suitable and relevant for the learning tools in the selected $\mathrm{KD}$. The result show that learning using the E-Module Conflict Resolution as a learning medium for high school students or equivalent is declared more effective and practical. This is based on the comparative data obtained.
\end{abstract}

Keyword: Conflict Resolution, E-Module Conflict Resolution, Pancasila Value 


\section{Introduction}

The number of high school students/equivalent conflict cases in Indonesia has increased due to the inability of students to resolve conflicts constructively and personally. In addition, it is also caused by biological factors: theory Strungle for Live that strong individuals will oppress weak individuals. Factor racialist; beautiful people are treated with more special. Psychological factors, conflicts between personalities. Personality factors Concepscentia dominant; the domination of a person who is coercive/hard/vicious. More emotional and tend to use harsh words. There are Llack of experience because problems are used to being solved by other people inability to understand other people's point of view.

Have a high ego so that they think they don't need and even refuse help from others, and the visualization of image of education that grows gab. From the 2019 criminal statistics, it is known that the percentage of mass conflicts between high school/equivalent students in West Sumatra has increased, from 2014 which was only $0.40 \%$ to $0.65 \%$ in 2018 . Then, in 2019 it increased by $4 \%$. from the previous year (Sub-directorate of Political and Security Statistics 2019). This is not much different in 2020 which also experienced an increase of 5\% from the percentage in 2019 (Sub-directorate of Political and Security Statistics 2020). Based on the data above, $9.65 \%$ of all cases that occurred; there were 115 cases of sexual violence against children, the majority of which occurred in high school students/equivalent, 498 cases of brawls of which 399 cases were dominated by high school students/equivalent, and bullying 120 cases ofand 98 cases were carried out by high school students/equivalent.

Based on the initial observations and interviews that the researchers conducted with high school and vocational high school students with the initials "R" and "A" it was obtained information that so far the conflicts faced by high school students/equivalent are; (1) brawls caused by various things, especially romance issues, (2) bullying that is motivated by the desire to be recognized as strong and influential by dominating the lives and affairs of students who are considered weak, (3) discrimination in science and social studies because of the feeling that their majors are greater compared to other majors, (4) the existence of gangs that divide them up with the intention of showing the difference between 
them and other students because of the desire to be more prominent and recognized for their existence, (5) skipping school due to the desire to be given more attention by families, especially parents, teachers, schools and friends. (6) smoking is caused by the desire to be recognized that they are adults, (7) drugs are caused by the desire to look cool when able to cross the limits prohibited by adults, and (8) promiscuity is caused by uncontrolled romance, unstable emotions and not getting strict supervision from various parties. In relation to the resolution of these conflicts, various efforts to prevent and resolve conflicts have been carried out by various parties, starting with forming a community of peacemakers and maintainers among students of various levels, empowering youth, making various forms of educational activities about peace, and imposing strict sanctions. ,increased control from various parties; parents/families, schools, teachers, communities, and the state through their security apparatus.

However, this is not enough to control the percentage increase in conflict, especially mass conflicts such as brawls and bullying that occur among high school students/equivalent. Therefore, through this study, researchers offer other alternative solutions to be used in this problem by designing and producing conflict resolution modules as practical learning media for high school students / equivalent in understanding and resolving conflicts by linking them with one of the Basic Competencies (KD). which is taught in the Civics subject of SMA class XII semester 1, namely the relevance of the application of Pancasila values in analyzing cases of violations and denial of the rights and obligations of citizens.

The E-Modul was chosen because the E-Module can help readers (high school students/equivalent) to understand various alternative conflict resolutions that require convenience for the reader because there is a concept selfintroduction, namely independent learning without depending on others, providing comprehensive information about conflicts and settlement (self-contained), do not need other tools to understand or called stand alone, adaptive, or is flexible, which can be adjusted utilization in various types and place and different time spans. In addition, it also requires user-friendliness, which is made using lighter language (not using uncommon terms) to be easily understood by people from various backgrounds. It is known that previously a lot of research has been done 
on the creation and development of conflict resolution modules. However, from all of this, there has not been a module that specifically targets high school students in helping them to deal with and resolve conflicts. However, the module targets for all teenagers, early teens (junior high school students), middle teens (high school students) and college students (students) and even includes the general public. So the format of the module used also does not use a format that is attractive to high school students. These modules are designed in the form of training modules, development modules, and learning modules.

Some previous research, for instance (Sutrisno, 2018) asserted that module as a learning medium has been widely agreed upon, to provide information and knowledge. It focus on vocational senior high school that contained integrated education character. Supratikya, (2011) confirmed that a good module requires convenience for the reader because there is a concept of self-instruction namely independent learning without depending on others. When the reader reads a module, he gets comprehensive knowledge related to the theme, which is called self contained (Firza \& Karima, 2018). Other finding was also said that the module does not need other tools to understand it or is called stand alone (Zaki 2009) and a good module is also adaptive (Suyasa, 2017) or flexible (Widyaningrum, 2013), which can be adjusted for use in different types and places and in different timescales. In addition, a good module also requires user friendly (Suarsana, 2013), which is made using lighter language (not using uncommon terms) to be easily understood by the public (Surya Dharma, 2008).

This research was so different, because focus on E-Module and contained conflict resolution. Furthermore, the urgency of this research produced a conflict resolution E-module for $\mathrm{KD}$ relevance to the application of Pancasila values in analyzing cases of violations and denial of the rights and obligations of citizens, in the subject of Civics in SMA class XII semester 1. This study carried out three important steps; First, sort out the main issues of conflict between high school students/equivalent so that it is known what conflicts involve high school students/equivalent. Second, to design a Conflict Resolution E-Module for High School Students/equivalent in understanding and resolving conflicts, by linking it to one of the Basic Competencies (KD) taught in PPKn Class XII semester 1. 
Third, testing the E-Module to High School Students. /equivalent and then analyze the data that has been collected to determine the effectiveness and practicality of the products produced in the form of Conflict Resolution EModules for High School Students/equivalent by comparing student learning outcomes before and after using the E-Module. So that it can help students recognize various cases of violations and denial of the rights and obligations of citizens, can raise awareness of their rights and obligations as citizens, and can become good citizens who can avoid or manage conflict properly.

\section{Methods}

The type of research is Research and Development, which is a research method that is intentionally and systematically aimed or directed at being able to find or formulate products, models, media, methods, certain strategies that are more effective, efficient and innovative (Putra 2012). The product produced in this research is a conflict resolution module; practical learning media for high school students / equivalent in understanding and resolving conflicts through KD the relevance of the application of Pancasila values in analyzing cases of violations and denial of rights and obligations of citizens, in the subject of Civics in SMA class XII semester 1. The research model used in This research is Plomp's research model which is an adaptation of the model developed by Tjeerd Plomyang. This model was chosen because it is more systematic, directed, suitable and relevant for the learning tools in the selected KD (Plomp 2013).

\section{Results and Discussion}

\section{E-Module Conflict Resolution for Students Senior High School}

The module is one of the learning resources that serves to help students learn independently by using learning program that complete (Sumpeno, 2011) and whole (Ananda, Azwar 2014) and systematic is presented communicatively (Nahrowi, 2015) with the aim of facilitating module users (Sutrisno, 2008), in this case students (high school students/equivalent) in realizing the purpose of making the module in accordance with the content (Sutrisno, 2018). The module is a visual medium to convey messages or knowledge that makes it easier for 
messages or knowledge to be recorded in memory $75-80 \%$, can also support changes in attitude values and skills values of a maximum of $80 \%$ because based on investigations, the ability of the five senses of sight to receive messages is very important. which is $82 \%$ compared to the other five senses as well as written in the Cone of Experience dale (Supratikya 2011). Modules are life skills training that can help module users develop a certain skill which in the manufacturing process focuses on a particular topic with 9 components that make up the structure of the module body, namely topics, objectives, time, spatial planning, materials, procedures, media, evaluation and sources and must be equipped with worksheets for module users as further self-development (Supratikya, 2011).

The module must appear (inside and outside) attractive and characterize the purpose of making the module, display an introduction, present a table of contents, instructions for using the module, introductory chapters and visual images. generated through at least 7 stages, namely data collection, module design, design validation, design revision, product testing, product revision and mass production (Rahmawati, 2019; Hendriyani, et al., 2020). The module is presented in an attractive format according to the target user of the module and contains a comprehensive but concise series of material, easy to understand with the help of images. As well as presenting instructions for using the module which is a vital part of a module (Ramadhani, 2016; Puspita \& Hasyim, 2021; Suhono, \& Sari, 2020). It must be simple and applicable so that it is easily understood by users (Faturrohman, 2015).

In addition to print modules, other products are also known, namely EModules or digital modules that can be made using technology open source with applications open office ( Suarsana, 2013). E-modules were created by going through several stages in accordance with the Plomp approach by considering the developments of the times, the majority of which have taken advantage of advances in science and technology and have been proven to be effective in helping users understand the learning delivered in E-Modules (Suarsana, 2013). Today, E-Modules are used in many fields or aspects of science, in fostering public awareness of the importance of peace and mutual understanding so that a group is formed that is willing and willing to voluntarily take preventive action 
(conflict resolution agent) through the creation of a peace module (Suarsana, 2013; Supratikya, 2011).

A module can function effectively if (1) the discussion material in the module is simple, (2) the question sentences are not many, (3) the opinions of experts are separated into a separate section, (4) do not use foreign terms, (5) do not use difficult words but words that are more popular for users, (6) provide training steps in the form of points, (7) use simpler language, (8) use caricature pictures, and (9) complete pictures (Firza \& Karima 2018; Giawa, T., Montessori, M., \& Yusuf, 2021; Susanto, 2017). It can be concluded that the E-Module is a learning media that can provide a visual experience to the user so that it can increase the user's learning motivation towards the material to be presented in the module, can clarify and simplify the concept of a complex and abstract understanding so that it can become simpler, real and easy to understand by different users (Susanti, et al., 2020; Delima, 2018; Hamid, et al., 2020) Or simply it can be said that the module is a learning media that is valid, practical and effective and can create a fun and implementable learning atmosphere.

The urgency of this research is to produce a conflict resolution E-module for $\mathrm{KD}$ relevance to the application of Pancasila values in analyzing cases of violations and denial of the rights and obligations of citizens, in the subject of Civics in SMA class XII semester 1. This study carried out three important steps; First, sort out the main issues of conflict between high school students/equivalent so that it is known what conflicts involve high school students/equivalent. Second, to design a Conflict Resolution E-Module for High School Students/equivalent in understanding and resolving conflicts, by linking it to one of the Basic Competencies (KD) taught in PPKn Class XII semester 1. Third, testing the EModule to High School Students. /equivalent and then analyze the data that has been collected to determine the effectiveness and practicality of the products produced in the form of Resolution E-Modules Conflict for High School Students/equivalent by comparing student learning outcomes before and after using the E-Module. So that it can help students recognize various cases of violations and denial of the rights and obligations of citizens, can raise awareness 
of their rights and obligations as citizens, and can become good citizens who can avoid or manage conflict properly.

The number of high school students/equivalent conflict cases in Indonesia has increased due to the inability of students to resolve conflicts constructively and personally (Syafutra, Montessori, \& Suhono, 2021). In addition, it is also caused by biological factors; theory Strungle for Live that strong individuals will oppress weak individuals. factor racialist; beautiful people are treated with more special. Psychological factors, conflicts between personalities. personality factors Concepscentia dominant; the domination of a person who is coercive/hard/vicious. More emotional and tend to use harsh words. Lack of experience because problems are used to being solved by other people. Inability to understand other people's point of view. Have a high ego so that they think they don't need and even refuse help from others. And the visualization/image of education that grows gab.

From the 2019 criminal statistics, it is known that the percentage of mass conflicts between high school/equivalent students in West Sumatra has increased, from 2014 which was only $0.40 \%$ to $0.65 \%$ in 2018 . Then, in 2019 it increased by $4 \%$. from the previous year (Sub-directorate of Political and Security Statistics 2019). This is not much different in 2020 which also experienced an increase of $5 \%$ from the percentage in 2019 (Sub-directorate of Political and Security Statistics, 2020). Based on the data above, $9.65 \%$ of all cases that occurred; There were 115 cases of sexual violence against children whose minority occurred in high school students/equivalent, 498 cases of brawls of which 399 cases were dominated by high school students/equivalent, and bullying 120 cases of and 98 cases were carried out by high school students/equivalent.

Based on the initial observations and interviews that the researchers conducted with high school and vocational students with the initials "R" and "A" it was obtained information that so far the conflicts faced by high school students/equivalent are; (1) brawls caused by various things, especially romance issues, (2) bullying that is motivated by the desire to be recognized as strong and influential by dominating the lives and affairs of students who are considered weak, (3) discrimination in science and social studies because of the feeling that 
their majors are greater compared to other majors, (4) the existence of gangs that divide them up with the intention of showing the difference between them and other students because of the desire to be more prominent and recognized for their existence, (5) skipping school due to the desire to be given more attention by families, especially parents, teachers, schools and friends. (6) smoking is caused by the desire to be recognized that they are adults, (7) drugs are caused by the desire to look cooler when able to cross the limits prohibited by adults, and (8) promiscuity is caused by uncontrolled romance, unstable emotions and not getting strict supervision from parents or families, teachers and schools.

In relation to the resolution of these conflicts, various efforts to prevent and resolve conflicts have been carried out by various parties, starting with forming a community of peacemakers and maintainers among students of various levels, empowering youth, making various forms of educational activities about peace, and imposing strict sanctions, Increased control from various parties; parents/families, schools, teachers, communities, and the state through their security apparatus. However, this is not enough to control the percentage increase in conflict, especially mass conflicts such as brawls and bullying that occur among high school students/equivalent. Therefore, through this study, researchers offer other alternative solutions to be used in this problem by designing and producing conflict resolution modules as practical learning media for high school students / equivalent in understanding and resolving conflicts by linking them with one of the Basic Competencies (KD). which is taught in the Civics subject of SMA class XII semester 1, namely the relevance of the application of Pancasila values in analyzing cases of violations and denial of the rights and obligations of citizens.

The E-Modul was chosen because the E-Module can help readers (high school students/equivalent) to understand various alternative conflict resolutions that require convenience for the reader because there is aconcept self-introduction, namely independent learning without depending on others, providing comprehensive information about conflicts and settlement (self-contained), do not need other tools to understand or called stand alone, adaptive, or is flexible, which can be adjusted utilization in various types and place and different time 
spans. In addition, it also requires user-friendliness, which is made using lighter language (not using uncommon terms) to be easily understood by people from various backgrounds.

It is known that previously a lot of research has been done on the creation and development of conflict resolution modules. However, from all of this, there is no module that specifically targets high school students/equivalent in helping them to deal with and resolve conflicts. However, the target of the module is for all teenagers, early teens (junior high school students/equivalent), middle teens (high school students/equivalent) and college students (students) and even includes the general public. So that the format of the module used also does not use a format that is attractive to high school students/equivalent. These modules are designed in the form of training modules, development modules, and learning modules.

Therefore, the researchers in this study designed and produced a module that was specifically targeted for high school students/equivalent by linking it to one of the Basic Competencies (KD) in Civics lessons for class XII semester 1. With the aim of helping students recognize various cases of violations and denial of the rights and obligations of citizens so that awareness of their rights and obligations as citizens can grow, with the hope of becoming good citizens who can avoid or manage conflicts properly so as to reduce the number of conflicts that occur involving high school students/equivalent.

In this conflict resolution module consists of 3 material components; 1) causes of violations of rights and denial of obligations of citizens, 2) examples of cases of violations of rights and denial of obligations of citizens, and 3) efforts to handle rights and denial of obligations of citizens. These materials are packaged in semi-comic form; a combination of images and text with a blend of various colors. 

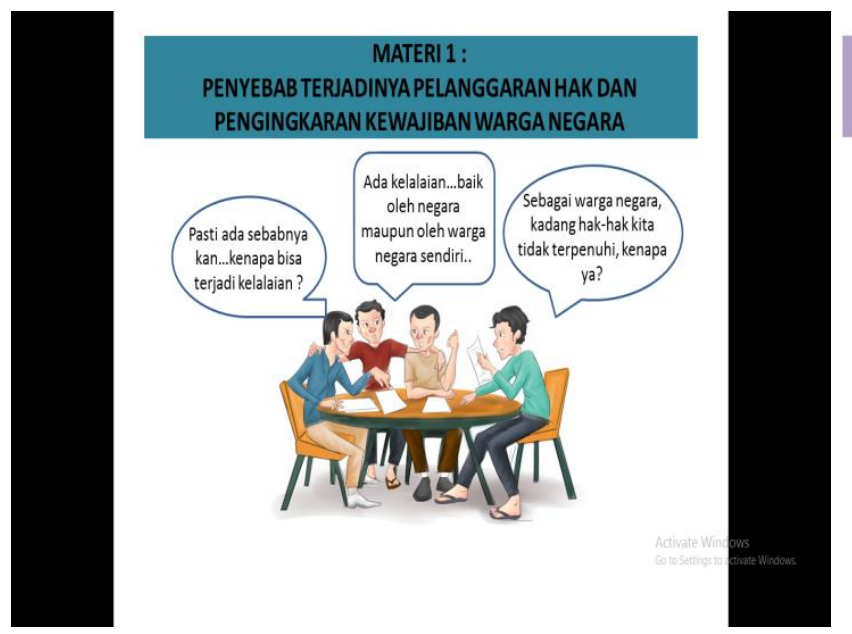

PENDIDIKAN KARAKTER YANG BELUM OPTIMAL SERTA PENGAWASAN YANG MINIM TERHADAP PELAKU PHYSICAL BULLYING DI SEKOLAH
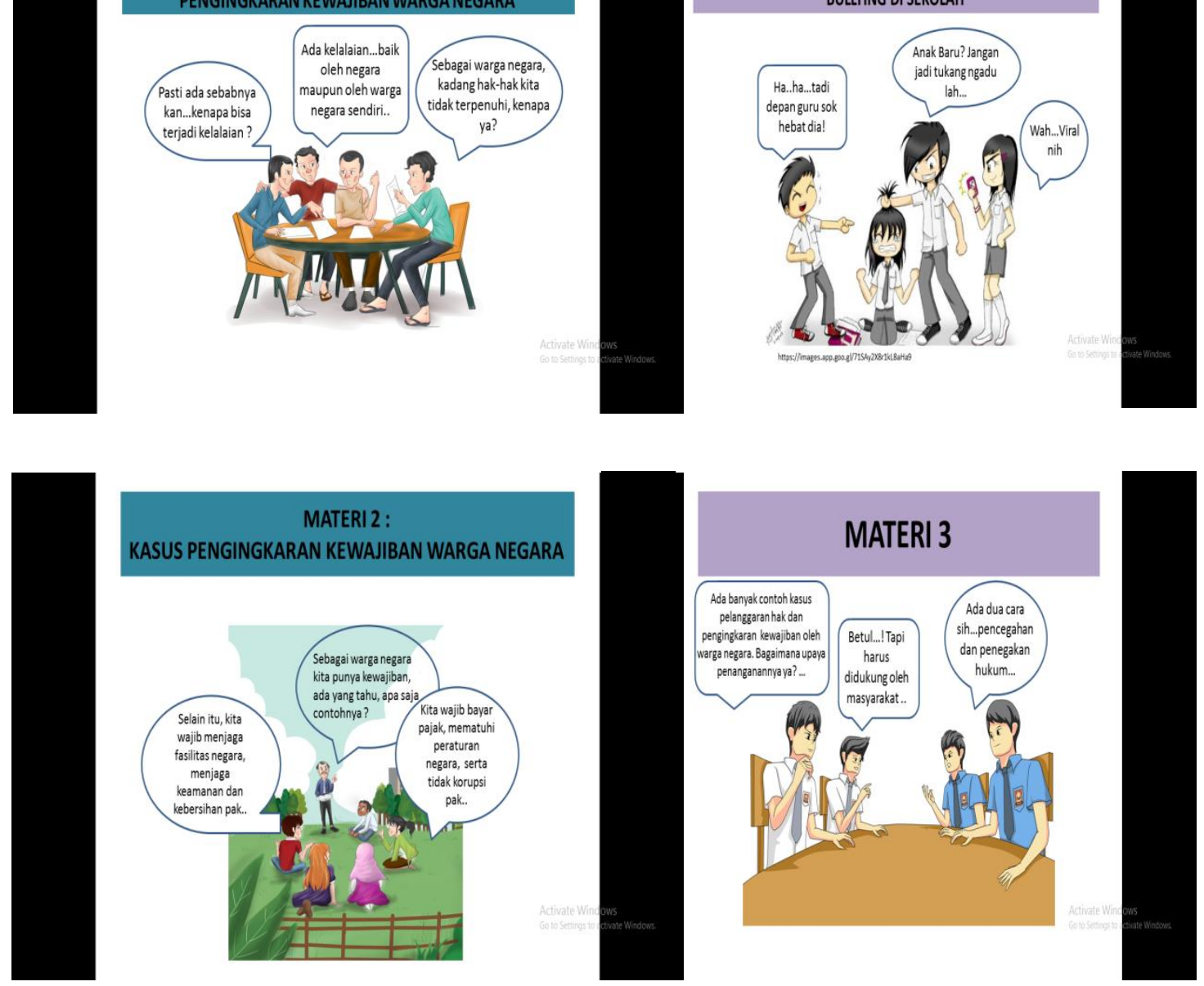

Figure 1. Material 1 E-Module Semi Comics

Apart from these 3 materials, the semi-comic e-module also consists of several components, namely; 1) cover, 2) introduction, 3) objectives, 4) 3 material, 5) summary, 6) formative test, 7) video, 8) answer key from formative test, 9) list of references, and 10) words of hope for reader. This semi-comic emodule is presented in 26 pages. Equipped with a combination of letters and 
images. As an effort to make this learning media more attractive for teenagers of the age of high school students/equivalent. So that what is to be conveyed in the emodule can be conveyed easily and well to students.
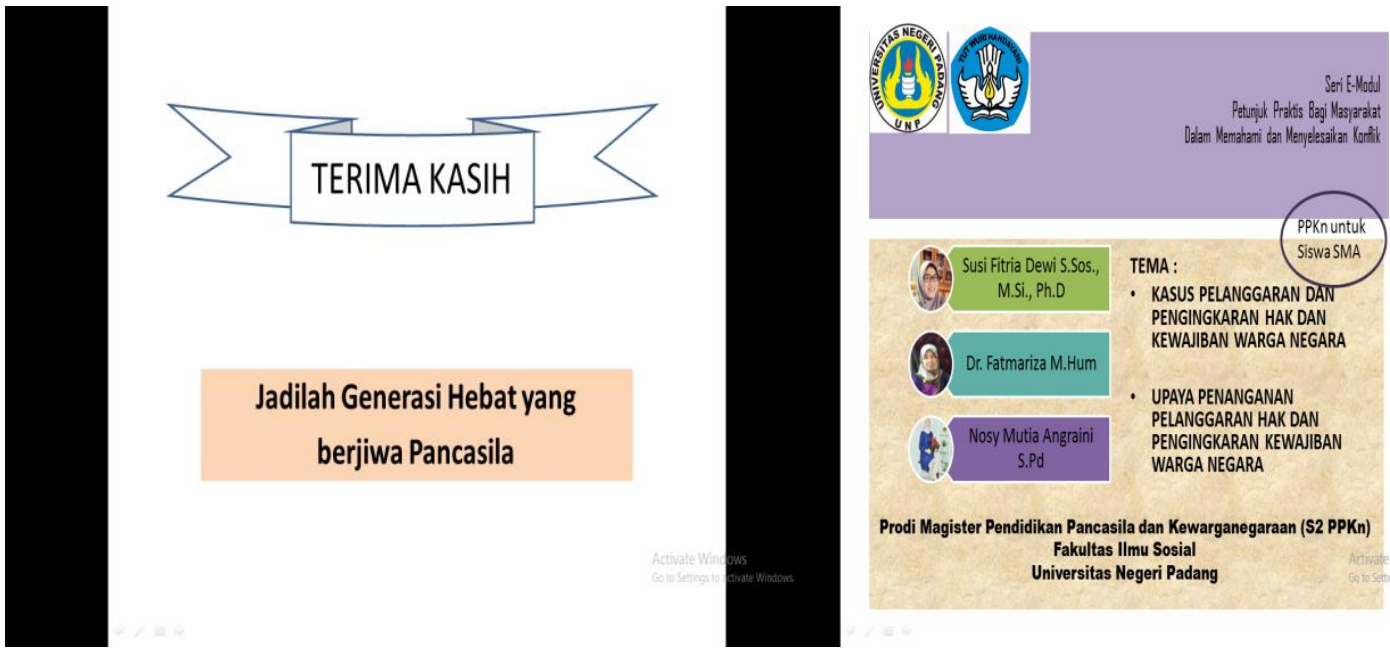

\section{berjiwa Pancasila \\ Jadilah Generasi Hebat yang}

Figure 2. Semi Comic E-Modul Cover Semi Comic

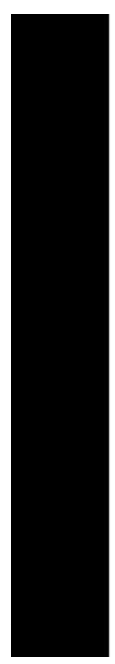

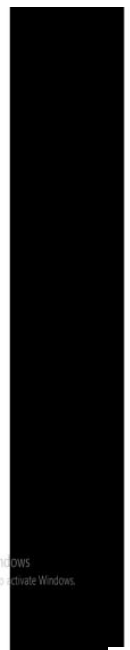

\section{TUGAS:}

SAKSIKAN VIDEO PENANGANAN PELANGGARANHAK DAN PENGINGKARAN KEWAJIBANWARGANEGARA

\section{MEMENTINGKANDIRI SENDIRI}

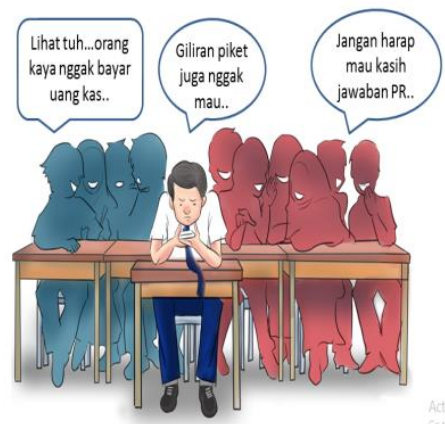

1.Penegakan Supremasi Hukum

https://www.youtube.com/watch?v=NFverM SwQ8.

2. Optimalisasi Peran Lembaga Berwenang https://www.youtube.com/watch?v=-1qifNiFOil

3. Meningkatan kualitas Pelayanan Publik https://www.youtube.com/watch?v=NHoc1Fh HIA

4. Penyebar Luasan prinsip-prinsip kesadaran bernegara melalui Pendidikan https://www.youtube.com/watch?v=10akb88EKZ8

5. Kerjasama antar kelompok

https://www.youtube.com/watch?v=U53ih66i1RRw

6. Penangkapan pelaku tindak Pidana

https: //www.youtube.com/watch?v=fay 5WzVov s

7. Lembaga peradilan menjatuhkan vonis

https://www.youtube.com/watch?v=xkaXsED2HHM

Figure 3. Semi Comic E-Module Video 


\section{Analyzing Cases of Violation and Denial of Citizen Rights and Obligations in Class XII 1st semester of PPKn}

E-Module Conflict Resolution for high school students/equivalent has been tested on high school students in class XII semester 1 with 69 students. 20 multiple question questions are given in the form of a google form. This question was given twice, the first was given when the lesson in KD "The Relevance of the Application of Pancasila Values in Analyzing Cases of Violation and Denial of Rights and Obligations of Citizens in the PPKn Subject of SMA Class XII Semester 1" was studied without using the E-Module. After getting the results, the E-Modules were distributed to high school students to be used as E-Modules as learning media.

In addition, an observation sheet with a google form format was also distributed to obtain high school students' opinions on the Conflict Resolution EModul which was provided as a learning medium. And then just redistributed the same 20 questions to students. The student learning outcomes obtained by using the E-Module and without using the E-Module were compared to the two. And based on this, it is known that learning using the Conflict Resolution E-Module as a learning medium for high school students / equivalent is declared more effective and practical. This is based on the comparative data obtained. It is known that the average learning outcomes of high school students / equivalent after using the EModul have increased from before using the E-Modul as a learning medium.

Table 1. Assessment Indicators of E-Module Conflict Resolution

\begin{tabular}{|c|c|c|c|c|}
\hline No. & $\begin{array}{l}\text { E-Module Assessment } \\
\text { Indicator }\end{array}$ & Description & Average (Scale 1-4) & Percentage \\
\hline 1. & \multirow[t]{3}{*}{$\begin{array}{l}\text { Mastery of Material } \\
\text { Mastery of }\end{array}$} & $\begin{array}{l}\text { material presented is easy } \\
\text { to understand }\end{array}$ & 3.88 & 74.55 \\
\hline 2. & & $\begin{array}{l}\text { The story used is simple } \\
\text { and easy to understand }\end{array}$ & 3.84 & 73.40 \\
\hline 3. & & $\begin{array}{l}\text { Message what is conveyed } \\
\text { is clearly accepted by } \\
\text { students }\end{array}$ & 3.92 & 74.64 \\
\hline
\end{tabular}




\begin{tabular}{|c|c|c|c|c|}
\hline 4. & $\begin{array}{l}\text { Ease of Use of E- } \\
\text { Modules }\end{array}$ & $\begin{array}{l}\text { There is ease in using } \\
\text { media }\end{array}$ & 3.92 & 74.93 \\
\hline $\begin{array}{c}5 . \\
\text { Th } \\
\text { e }\end{array}$ & & $\begin{array}{l}\text { clarity of the learning flow } \\
\text { is easy to understand }\end{array}$ & 3.76 & 72.73 \\
\hline $\begin{array}{c}6 . \\
\text { Th } \\
\text { e }\end{array}$ & & $\begin{array}{l}\text { language used is easy } \\
\text { understood }\end{array}$ & 3.98 & 76.17 \\
\hline 7. & Benefits of E-Module & $\begin{array}{l}\text { The benefits used can } \\
\text { increase students' interest } \\
\text { in reading }\end{array}$ & 3.82 & 73.11 \\
\hline 8. & & $\begin{array}{l}\text { Increase student interest in } \\
\text { learning }\end{array}$ & 3.85 & 74.35 \\
\hline 9. & & $\begin{array}{l}\text { Provide assistance in the } \\
\text { learning process }\end{array}$ & 3.92 & 73,97 \\
\hline 10. & & $\begin{array}{l}\text { Can be used for } \\
\text { independent study }\end{array}$ & 4 & 76.27 \\
\hline 11. & time & $\begin{array}{l}\text { time spentdalma short } \\
\text { learning }\end{array}$ & 3.62 & 70.05 \\
\hline 12. & & $\begin{array}{l}\text { the material presented in } \\
\text { accordance with the } \\
\text { available time }\end{array}$ & of 3.81 & 73.21 \\
\hline 13. & & $\begin{array}{l}\text { Problem tests given } \\
\text { according to the available } \\
\text { time }\end{array}$ & 3.72 & 71.96 \\
\hline
\end{tabular}

There are 4 indicators used in assessing the the E-Module Conflict Resolution with its 13 sub-indicators with an overall average obtained of 3.88 on a scale of 1-4 with a percentage of 73.8 . 
Table 2. Summary of Content Validity Score E-Module Conflict Resolution

\begin{tabular}{|c|c|c|c|}
\hline No. & Description & $\begin{array}{c}\text { Rekapitulai Score Validity } \\
\text { Material\% }\end{array}$ & Average \% \\
\hline 1. & Acquisition of presenting the feasibility score & 78.1 & \multirow[t]{2}{*}{79.1} \\
\hline 2 & Acquisition kebahasan eligibility score & 80.0 & \\
\hline
\end{tabular}

Table 3. Content validity Category

\begin{tabular}{|cc|}
\hline Achievement Level & category \\
\hline 81-100 & Highly Valid \\
\hline 61-80 & Valid \\
\hline 41-60 & Sufficiently Valid \\
\hline $21-40$ & Less Valid \\
\hline 0-20 & Invalid \\
\hline
\end{tabular}

Source: (Ridwan Adkon 2009)

The table above shows the data on the percentage of material validity of obtaining a presentation worthiness score of 78.1 while the percentage of material validity of obtaining a linguistic feasibility score is 80.0 with the average acquisition for both is $79.1 \%$. Based on the table of material validity categories (Ridwan Adkon 2009), it is known that the level of achievement of the Conflict Resolution E-Module for High School Students/equivalent is 61-80 so it can be declared valid.

This research contribute for the students in recognizing various cases violation and denial of the rights and obligations of citizens so that awareness of their rights and obligations as citizens can grow, with the hope of becoming good citizens who can avoid or manage conflicts well so as to reduce the number of conflicts that occur involving high school students/equivalent.

\section{Conclusion}

Based on the data above, it is known that learning using the E-Module Conflict Resolution as a learning medium for high school students/equivalent is 
declared more effective and practical. This is based on the comparative data obtained. It is known that the average learning outcomes of high school students / equivalent after using the E-Modul have increased from before using the E-Modul as a learning medium. There are 4 indicators used in assessing the E-Module Conflict Resolution with 13 sub-indicators with an overall average obtained of 3.88 on a scale of $1-4$ with a percentage of 73.8 . Based on the table of material validity categories (Ridwan Adkon 2009), it is known that the level of achievement of the Conflict Resolution E-Module for High School Students/equivalent is 61-80 so it can be declared valid.

\section{Acknowledgement}

The researchers thank to (LP2M) Universitas Negeri Padang. This work was also supported by Lembaga Penelitian dan Pengabdian Masyarakat (LP2M) Institut Agama Islam Ma'arif NU (IAIMNU) Metro Lampung

\section{References}

Ananda, A. A., \& Ramadhan, S. (2014). "Development of a Picture Module Equipped with Worksheets with a Suit Approach in Learning Organ System Materials for Even Semester XI Students.” Journal of PPS Biology I(1): 1-7. Delima, E. (2018, September). The importance of multimedia learning modules (mlms) based on local wisdom as an instructional media of 21st century physics learning. In Journal of Physics: Conference Series (Vol. 1097, No. 1, p. 012018). IOP Publishing.

Faturrahman, M. (2015). Innovative Learning Models. Yogyakarta.

Firza and Elfa Michellia Karima. 2018. "Green History-Based Module for History Learning in High School." Diachronic XVIII(2): 45-57.

Giawa, T., Montessori, M., \& Yusuf, M. (2021). An Analysis of the Teachers

Professionalism Performance of Pancasila and Civic Education at Padang City. JMKSP (Jurnal Manajemen, Kepemimpinan, dan Supervisi Pendidikan), 6(2), 236-258.

Hamid, M. A., Yuliawati, L., \& Aribowo, D. (2020). Feasibility of Electromechanical Basic Work E-Module as a New Learning Media for 
Vocational Students. Journal of Education and Learning (EduLearn), 14(2), 199-211.

Hendriyani, Y., Ambiyar, S., \& Effendi, H. (2020, December). The Development of Interactive Project Based E-Module in Visual Program Course. In 2nd International Conference Innovation in Education (ICoIE 2020) (pp. 236240). Atlantis Press.

Nahrowi, A. H. (2015). Leadership And Conflict Resolution Module For Women Parliamentary Candidates. Indonesia: Search for Common Ground.

Plomp, T \& Nieveen N. (2013). Educational Design Research. Enschede: Netherland: Institute for Curriculum Development (SLO).

Puspita, N., \& Hasyim, U. A. A. (2021). Book Club Discussion: An Extensive Reading Program in Writing Class. Attractive: Innovative Education Journal, 3(2), 113-123.

Putra, N. (2012). Research and Development. Bandung: Rosdakarya Youth.

Rahmawati, I. (2019). "Efforts to Control Juvenile Delinquency in Public High Schools (SMAN) East Kutai Regency in the Perspective of Islamic Education." Journal of Islamic Religious Education VII(1): 17-26.

Ramadhani, Hetti, S. (2016). "Adolescents' Interpersonal Conflict Resolution Ability After Participating in Conflict Resolution Outbound Training." Journal of Psychology V(3): 187-93.

Ridwan, A. (2009). Formulas and Data in Statistical Analysis for Research. Bandung: Alphabeta.

Suarsana, M and G. A Mahayukti. (2013). "Development of Problem-Solving Oriented E-Modules to Improve Students' Critical Thinking Skills." Indonesian Journal of Education II(2): 264-75.

Sub-directorate of Political and Security Statistics. (2019). "Sub-directorate of Political and Security Statistics." : 40-46.

Suhono, S., \& Sari, D. A. (2020). Developing Students' Worksheet Based Educational Comic for Eleventh Grade of Vocational High School Agriculture. Anglophile Journal, 1(1), 29-40.

Sumpeno, W. (2011). The PNPM Subdistrict Facilitator Training Module for Healthy Smart Generation. Jakarta: Ministry of Home Affairs of the 
Republic of Indonesia.

Supratikya, A. (2011). Designing Programs and Modules. Yogyakarta: Sanata

Dharma Press University.

Surya, D. (2008). Writing Modules. Jakarta: Ministry of National Education.

Susanti, R. (2017). Pengembangan Modul Pembelajaran PAI Berbasis Kurikulum 2013 di Kelas V SD Negeri 21 Batubasa, Tanah Datar [Development of Islamic Education Learning Modules Based on 2013 Curriculum in Class V SD Negeri 21 Batubasa, Tanah Datar]. JMKSP (Jurnal Manajemen, Kepemimpinan, dan Supervisi Pendidikan), 2(2), 156-172.

Susanti, N., Yennita, Y., \& Azhar, A. (2020). Development of Contextual Based Electronic Global Warming Modules Using Flipbook Applications as Physics Learning Media in High Schools. Journal of Educational Sciences, 4(3), 541-559.

Sutrisno, J. (2018). Module Preparation Techniques. Jakarta: Directorate of Vocational Intermediate Development.

Suyasa, P. Wayan Arta et al. (2017). "Empowerment of Open Source Technology in Making Digital Modules for Lecturers in the Stikes Bulelang Environment." Widya Laksana VI(2): 120-29.

Syafutra, S., Montessori, M., \& Suhono, S. (2021). Local Awareness in Making Social Integration of Society at Mendahara District. JMKSP (Jurnal Manajemen, Kepemimpinan, dan Supervisi Pendidikan), 6(2), 278-292.

Widyaningrum, R. et al. (2013). "Development of Environmentally Insight POE Oriented Modules on Pollution Materials to Improve Student Learning Outcomes." Journal of Bioeducation VI(1): 100-117.

Zaki, R., \& Fatwa, S. T. D. (2009). "The Effectiveness of Role Play, VCD Shows and Modules in Improving Therapeutic Communication Skills of Stikes General Ahmad Yani Yogyakarta Students." Journal of Public Medicine News XXV(3): 125-32. 